\title{
RE-THINKING THE MODERN LEADERSHIP IN THE ROMANIAN ORTHODOX CHURCH IN THE CONTEXT OF ROMANIA'S EUROPEAN MEMBERSHIP
}

\author{
Mihail TEACĂ, Assistant Professor PhD Student \\ Foundation for Promoting the European Education - WUR \\ Email: mihail.teaca@yahoo.com \\ Sebastian CHIRIMBU, Lecturer PhD \\ Spiru Haret University, Faculty of Letters \\ Email: sebastian_chirimbu@yahoo.com
}

\begin{abstract}
The article highlights the issue of leadership within the Romanian Orthodox Church, as it is going through a period of redefinition of its values. Connections between organizational culture, management culture and leadership in modern organizations highlight the manner in which leadership is exercised in the context of knowledge of the organization's foundation.
\end{abstract} novation

Keywords: leadership, managerial approaches, religious organizations,

JEL Classification: $\mathrm{D}_{80}, \mathrm{M}_{14}$

\section{Introduction}

In the recent period there have been talks about the Church-State relationship in the European Romania of the year 2014, on the one hand a certain part of the press denigrating the Church as a whole, and on the other hand in the vast majority of the surveys of the General Church enjoys great confidence. In times of crisis, people are more willing to come back to God, seek Him more, being the last solution, but also the best. One cannot speak about the Romanians without talking about the Church, be it the Orthodox, Roman Catholic, Greek Catholic, or Protestant, with its various ramifications. The national unity of the Romanian people has been formed around the Church.

The integration into the European Union in 2007 meant besides the advantages, many responsibilities, that the Romanian diaspora is present in many EU Member States.

By the appointment of the Metropolitan of Moldavia and Bukovina, His Eminence Metropolitan Daniel Ciobotea, $\mathrm{PhD}$ as the 6th Patriarch of the Romanian Orthodox Church, on 30 September 2007, the Church has entered into a new stage of development in the media plan, by establishing the Trinitas TV station, the Trinitas radio station which lead to a greater involvement in the social life and community. 
Each Patriarch was a man of his time, preserving the unity of the Romanian people. All churches have an important role in what is now Romania, but we will discuss within the present study the work of the Romanian Orthodox Church, which although officially does not have this Statute, may be called the National Church.

\section{Terminological distinctions between the concepts of management and leadership}

There is a terminological distinction between the concepts of management and leadership.

In their work The Secret of Management. The Ability to Lead, the authors: G. Toma and C. Baltă believe that "in the specialized language was especially used the term of Anglo-Saxon origin that is management, with a particularly complex semantics, including in its content what in Romanian language is rendered by the term driving" (Toma G., Baltă C., 2001, p. 9).

One can talk about management, and leadership ever since ancient times; in The Old Testament in particular, but also in the New Testament we find many examples of leaders: Abraham, Moses, David, Solomon, and Jesus Christ, Peter, Paul, and others who have marked the history of the times and the places where they lived.

On the art of leadership, we find references in the works of ancient Greek philosophers, Plato, speaking for the first time in his Dialogues about what we understand now by the concept of leadership. The author of the Republic shows that virtue is power to lead people, a thing that can be achieved only if a person has strong views and science.

Innumerable books have been written on the art of leading people, and it is a very popular topic in organizational behaviour, having a role in defining the performance of organizations and groups. Studies of leadership are more than a few thousand, but each period of research has failed to produce a full understanding of leadership. (Stogdill R., 1974)

Intuitively, for everyone who has knowledge in the field, it is something understood that leadership means leading people and influencing what they are doing or causing others to follow you. Leadership can be interpreted as a function of the personality or behavioural component, can be an attribute of the hierarchical position or could be defined as proven knowledge or intelligence.

Management is the process of fixing and attaining the objectives of the organization by using the functions of management: planning, organizing, leading (or leadership) and to control administrative and business activities, planning, implementation, monitoring and achievement of results, all conducted under the aegis of formal authority. In principle, leadership deals with the interpersonal aspects of the work, while managers are more related with the planning, organizing and control of administrative aspects.

J. Hunter writes in The Servant (1998:29-34) that "If leadership is about influencing others, how do we go about developing that influence with people? 
How do we get people to do our will? How do we get their ideas, commitment, creativity, and excellence, which are by definition voluntary gifts?" (http://c2.com/cgi/wiki?PowerVersusAuthority) To better understand how one develops this type of influence, it is critical to understand the difference between power and authority. ...It must be acknowledged that Christians are not always comfortable with the idea that to lead is to use power (Carter J.F., 2009, p. 186)

Leadership is more than just power and authority, it adds a person's own effort, vision, boldness and unique personal qualities, stimulating the process of leadership. Leadership deals with change, inspiring, motivating, and influencing, while management is responsible for the executive, which would lead to the fulfilment of the objectives of the Organization and maintain balance in its interior.

The main point of differentiation between leadership and management, is that members of an organization, employees are volunteer leaders, because they want it, not because it would have required. The leaders do not possess the formal power to reward or penalize performance, members of the organization provide leadership through the power to carry over to their requirements. On the other hand, managers must appeal to the formal authority with which they were consenting, to do as members of the organization to fulfil its objectives.

Although management and leadership do not define the same terms, they are often used, interchangeably. Lately, there has been a tendency for managers to be considered or to be called leaders, which is probably due to the fact that we live in the age of globalization, where although we're a francophone state we have borrowed English terms, which sometimes are not fully understood. In theory, the leadership is considered as a function of management, and it can be one of the explanations for which any manager has the quality of leadership, not just the formal function. At the opposite pole, there are leaders who do not occupy any position of management, which are informal leaders. Reality has shown that managers should be interested, motivated to become leaders, but this would entail to rely less on formal function and on appointment to a management position.

\section{Leaders and leadership}

"Leadership is a dynamic relationship, based on common goals and mutual influence between leaders and employees, in which both sides have reached high levels of motivation and moral development, while producing real deliberate change". (Freiberg K., Freiberg J., 1996, p. 298)

Leadership involves a voluntary support from the Organization's members, leaders should not simply lead through the directive, but by persuasion, motivation, empowerment, delegating, while identifying and earning involvement for a stimulating and challenging vision. Leaders not only manage the performance of individuals, but also that of the group.

In the specialized literature, it is stated that "Leadership is the capacity to transform the vision into reality," (W. Benis, 1997, p. 102), and it is explained that taking account of his visionary capabilities, a leader must be a good architect and a social, visionary that is, the man who understands the Organization and is also able 
to improve its mode of operation. Also, this literature talks about the attributes that a leader has to possess: consistency, commitment, accepting challenges, strength, willingness to assume risks and losses, charisma, and above all, the ability to stay connected at all times to the new and to learn continuously.

Figure no. 1. Characteristics of managers vs. leaders

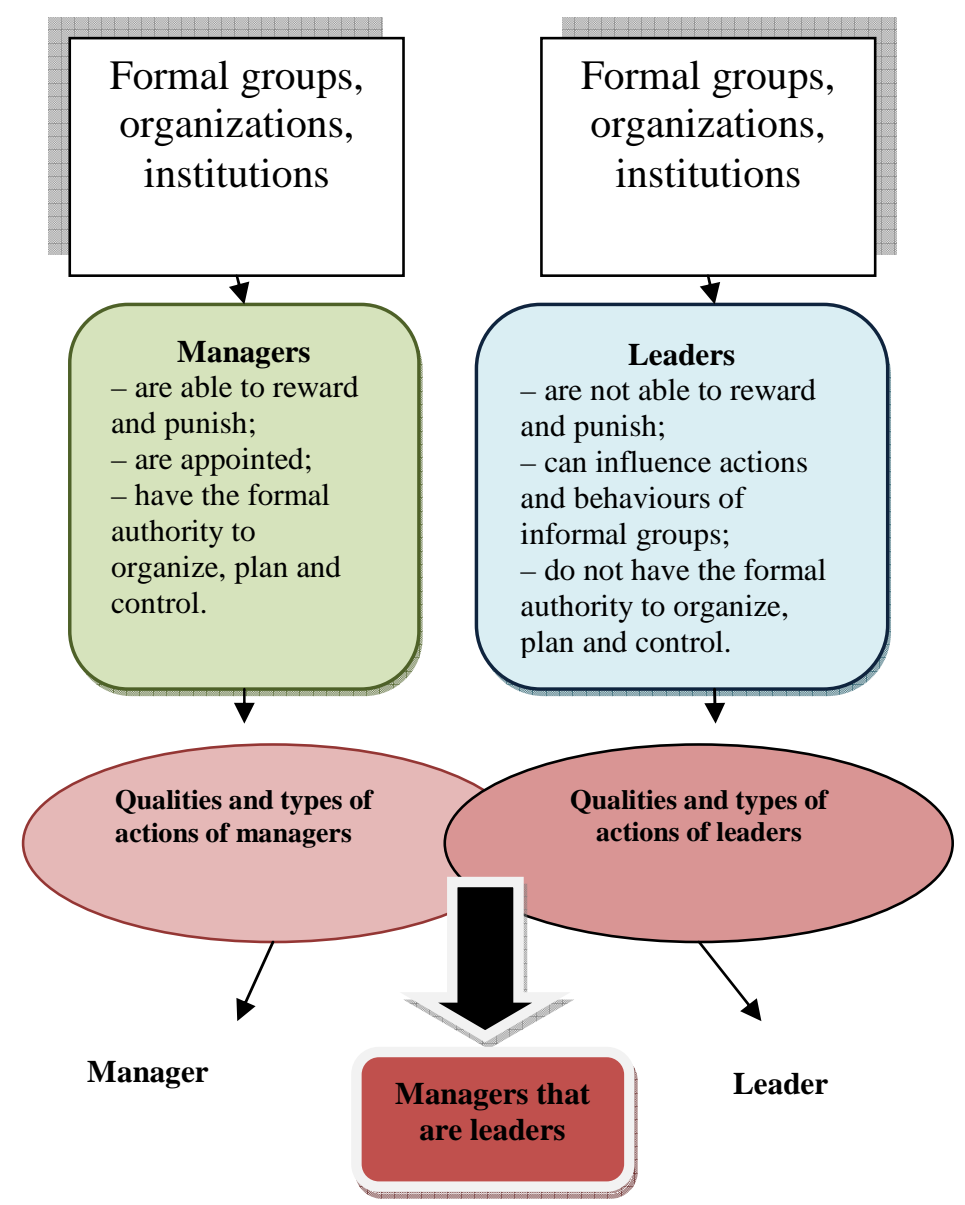

Source: M. Teacă, S. Chirimbu, "Observations on leadership in the context of current changes" in Interdisciplinarity as a Multidimensional Concept, ed. S. Chirimbu, Oradea: UEO, 2014, p. 235.

A leader is in a continuous training, and the best place for learning and training is the right organization in which they are located. Most leaders manage if they develop a set of skills, if they have the capacity to carry out and to share with other members of the organisation to tolerate errors, uncertainties, to meet the requirements related to the future, to know, to listen, to have interpersonal skills, but even more important to know themselves and to develop steadily. 


\section{The Church's involvement in the current society}

The State-Church relationship needs to be understood so that it can be identified as being part of different structures of power, this power being given either by legislation, or by membership in a church. In our modern history, the role of the Church was to serve the State, regardless of the type of government. The Church will last until the end of the ages, "Europe may recognize its Christian origins or not, but the world is evolving and at the same time with it, the ChurchState relationship is in constant transformation, beneficial to both sides. The fundamental distinction between the State and the Church is given by the fact that the recognition of the power of the State is as fleeting and luminous, secular, while the Church is divine, eternal. If the State is to restrict the social consequences of sin, the Church has the mission of guiding man towards the Kingdom of God. The State has a duty to ensure the freedom of all individuals and the freedom of the individual to believe anything and at any intensity, with the specification that this freedom must not affect or insult each other's freedom."

Within the European Union, freedom of religious worship is of particular importance, due to the particularities that distinguish them from all other States and non-State structures, constituting, at the same time, an integral part of the essence of the European culture.

Although the global and European tendency is towards an acceleration of secularisation, the latest censuses $(1992,2002,2011)$, showed that over $99.8 \%$ of citizens have religious membership, a plausible explanation being that in the Communist period, the Church was a refuge for the many, the Church was the one which continued to pray for a better day and a new beginning.

However, the relationship between State and Church has a high potential for conflict in Romania, There is also a conflict between the Romanian Orthodox Church and Greek Catholic Church as a result of the restitution of properties confiscated by the Communists from the Greek-Catholic Church. There have been a few cases in which only the intervention of the competent justice bodies have brought peace and restitution of property.

After 2007, the year of Romania's entry into the European Union, it was a difficult time for the relationship between educational institutions and religious communities. Today there is an important discussion related to the study of religion in schools. Some non-governmental organizations have called for the removal of icons and religious symbols in classrooms on the basis that this would violate the freedom of conscience of the pupils.

Another topic discussed at present is the very involvement of Churches and religious communities in general social-charity activities, supporting in this way the State in this area so vast and complex, and at the same time leading to the fulfilment of the commandments of the Saviour, to take care of those in distress and needs. The Romanian Government has signed a Document of cooperation with the Romanian Patriarchate as well as with representatives of the Conference of Catholic Bishops of both rites in Romania. Protestant churches and also the neo- 
Protestant ones, have a very well organized activity of involvement in social and charity work, issues dealt with by means specialised bodies.

With the signing in May 2000 of the Declaration of religious affairs for the integration of Romania into the European Union and of the Declaration of participants in a National Forum to support the process of accession of Romania to the EU in February 2003, the Romanian Orthodox Church showed openness to the spiritual values that underlie modern European unity. Since 2005 there has been a Permanent Office of the Romanian Orthodox Church in Brussels.

The accession to the European Union of majority Orthodox countries such as Greece, Cyprus Romania and Bulgaria as well as the fact that there are wellorganized Orthodox communities in countries such as Finland, Poland, the Czech Republic, Slovakia, the Baltic States, has made the Orthodox presence increasingly numerous in Western Europe due to the free movement of citizens for a better living as the Church did not only take note of this development policy but also deepened the impact of the European Churches and Christian life in general, and the contribution of orthodoxy to the European identity.

At the moment, there are accredited in addition to EU institutions five Offices of representation of the Orthodox churches, which although are all of Autocephalous Orthodox Churches, are United in the Orthodox faith and, represent the interests of a single voice.

\section{Modern Leadership in the Romanian Orthodox Church. The Patriarch Daniel Ciubotea}

Since September 30, 2007, the Romanian Orthodox Church has entered a period of extraordinary flowerishing by the appointment of Dr. Daniel Ciobotea to the dignity of Patriarch of the Romanian Orthodox Church. It has brought a new spirit to the Church, bringing it to where it was after the Communist dictatorship.

Another unique thing in the leadership of the Romanian Orthodox Church is the Patriarch's devolution right. The Patriarch is the only one who "exercises his right of devolution for the restoration of order and administration", (article 26, (b)). Devolution is a provision of Canon 11 of the 7th Ecumenical Council, which provides for this right of devolution "to restore law and order within a church". It refers to the Patriarch's right, as an upper administration to intervene in the Affairs of another subordinate administration, when the law is not applied or applied wrongly, as an exception to the internal autonomy. If it is found that in a Metropolitan Council, headed by Metropolitan, those appointed staff do not apply the correct ROC laws or defer to apply, he may intervene to restore the situation.

To be able to highlight the Church's activity, in 2008 the leading members of the ROC set up two publishing houses Basilica and Trinitas under the supervision and with the support of the Patriarchy. But the most important thing is taking up, supporting and supervising the work of building the People's Cathedral.

2011 brings the printer set up of the Pharos printing house in PopeştiLeordeni and organising the Memorial House "Archimandrite Arsenius Nada" by 
Holy Mary Monastery from Techirghiol. The Diocesan Centre in Bucharest was also reorganized, finding itself in a new location.

2012 is the year of modernisation: the library of the Holy Synod is modernized and the National Training Centre Dumitru Stăniloae of the Patriarchate is set up. As there are already facilities such as a printing and a publishing house as well as a press centre, the year 2012 shall also mean the set-up of the bookshop and the magazine "Word of life".

A great achievement of Patriarch Daniel Press Centre is the Basilica, founded on 27 October 2007, based initially in the Patriarchal Palace in Bucharest. The centre comprises five components: radio TRINITAS, TRINITAS TV television, a group of three publications (the Lumina (Light) newspaper, the only daily newspaper in the Orthodox world, the weekly Sunday Light, monthly magazine Orthodoxy), BASILICA, News Agency Press Office and public relations department.

Radio TRINITAS, the first Orthodox radio station set up in Romania (1998), is currently the radio station of the Romanian Patriarchate and helps to support cultural activity-missionary of the Romanian Orthodox Church. TRINITAS TV started its activity in Bucharest, on October 27, 2007, at the same time with the establishment of the BASILICA Press Centre, the two bodies forming an integral part of the Church's communication policy. Through this television, the Romanian Patriarchate informs the public, by means of words and images about the main events in the Church's life, about its pastoral-missionary, educational, social and cultural activity, bringing to the attention of the public interested in history, culture the Christian activity of the church in the European context.

The printed media is represented at the central level of the Romanian Patriarchate through three publications: the daily newspaper Lumina, a weekly publication, the Sunday Lumina and the monthly Orthodoxy, all made by the same editorial team efforts, joining the youth with professional journalism. The Lumina newspaper has been published without interruption from 7 February 2005, the only daily newspaper in Romania, and Christian at the same time, the only daily newspaper in the Orthodox Christian world. The Lumina newspaper is important not only for its informative role, but also for the formation of the Christian consciousness present and active in society.

The Church's News Agency's role is to present, in the form of news and documentaries, the institutions, activities and attitudes the Romanian Orthodox Church, as well as of other churches, and to offer specialized opinions in various current of a religious nature problems. The News Agency participates in the fulfilment of the original vocation of the Church to convey to the world the good news of salvation. In a society dominated by electronic communication of information, over-production and over-consumption, the religious information is intended to remind the people the need for discerning information, for making a distinction between ephemeral and perennial values between science and wisdom, between knowledge and profound communion with God and with people, uniting the freedom with responsibility in permanent personal life, social and family (Ciobotea, 2014). 
The most important missionary task carried out by the Patriarch from his election until today is that on 29 November 2007, when he laid the foundation stone for the People's Salvation Cathedral dedicated to St. Andrew and to Christ's Ascension. In the period May-October 2008 the current Patriarchal Cathedral named after the Holy Emperors Constantine and Elena was restored. Between 2008-2011 extensive restoration work was done to the patriarchal Residence.

In the administrative plan in 2009, the Church appointed six bishops to the rank of Archdiocese (Arad, Argeş, Buzău, Galaţi, Râmnic). The Orthodox Romanian Diaspora Church was reorganized, through the establishment of new dioceses: the Romanian Orthodox Diocese of Australia, the Romanian Orthodox Diocese of Italy, the Romanian Orthodox Diocese of Spain and Portugal, the Romanian Orthodox Bishopry of North Europe, and also the parishes for Romanians in Japan, Syria. In the year 2009, the Diocese of Deva and Hunedoara was set up, residing in the municipality of Deva and Hunedoara.

Romanian Saints were canonized, have organized celebrations and commemorations, which, in 2008, the year of the Holy Scripture reverential and liturgy, 2009 commemorative year proclaimed the Cappadocian Fathers, 2010 proclaimed the year of the Orthodox Creed and reverential of autocephaly proclaimed the year 2013, reverential of the Saints Constantine and Helen Kings in the Romanian Patriarchy and the commemorative year of Dumitru Stăniloae in schools of theology of the Romanian Patriarchate and 2014 is the year of the Saints and Martyrs Brâncoveanu.

All work submitted from his appointment until today, that Patriarch Daniel, has a church, a modern, is perhaps the best administrator of the Church of Christ, and certainly his name will remain in history as a great scholar, organizer of the monastic life, theological, the mandate of which the dream of a life of the Church will rise towards the eternal glory of God-Salvation Cathedral.

\section{Conclusions}

Leadership is one of the themes about which management researchers have talked and written so much in recent years as there are dozens of theories, thousands of articles. Yet little is known about what determines the success or failure of a leader. Unfortunately, there has not been found a single general formula applicable to be implemented and to ensure its success. As society as a whole, the Romanian Orthodox Church is going through a period of redefinition of its values. In a super technologized society the Church must be in step with what is happening in the lay world, otherwise, it will lose church members and it will have fewer souls saved. We have addressed the issues of religious leadership in a modern church pertaining to faith, not to the church's earthly objectives, as the ultimate goal of the Church is to reconcile man with God, and earthly leadership can contribute to a great extent to how it will achieve this objective. 


\section{REFERENCES}

Carter, J.F. (2009), "Power and Authority in Pentecostal Leadership", Asian Journal of Pentecostal Studies, vol. 12, issue 2, p. 186.

Ciobotea, D. (2014), Missionary communion. The church's work in community in 2013 (Comuniune şi înnoire misionară. Lucrarea Bisericii în societate în 2013), Bucharest: Basilica Publishing House.

Dragomirescu, H. (2001), Organizations based on knowledge. Thematic study, Bucharest: Romanian Academy, ASE, p. 3.

Freiberg K., and Freiberg J. (1996), Southwest Airlines crazy recipe for business and personal success, Austin: Bard Press, p. 298.

Hunter, J. (1998), The Servant. A Simple Story about the True Essence of Leadership, Prima, online source consulted: http://c2.com/cgi/wiki?PowerVersusAuthority

Stogdill, R. (1974), Handbook of Leadership: a survey of the literature, New York: Free Press.

Teacă, M., and Chirimbu, S. (2014), "Observations on leadership in the context of current changes", Interdisciplinary as a Multidimensional Concept, ed. S. Chirimbu, Oradea: UEO, p. 235.

Toma, G., and Baltă, C. (2001), Secret of management. Leading abilities (Secretul managementului. Abilitatea conducerii, Bucharest: CERES Publishing House, p. 9. 
